\title{
SINERGI EKUITAS, LOYALITAS, MARCOM DALAM MEREK
}

\author{
Endro Tri Susanto \\ Dosen Program Studi Disain Komunikasi Visual \\ Jurusan Disain, FSR ISI Yogyakarta \\ endro_tris@yahoo.com,endro_tris@yahoo.co.id
}

\begin{abstract}
Creating and building a brand requires a long effort to bring forth. Brand that has built up and established businesses need to always be present in the hearts of the audience. The retention of the brand in the minds of audiences require stratgei that consumers generally do not turn to other brands. Attempt to answer the question of the building equity and customer loyalty to a brand is a necessity.
\end{abstract}

Keywords: Brand Equity, Loyalty, Marketing Communication.

Relevance to Visual Communication Design Practice: Brand Equity, Loyalty, Marketing Communication is an integral part of the marketing activity in visual communication design. This discussion is expected to provide an overview of marketing synergies in that it can be supported from any side

\section{Merek}

Merek merupakan simbol yang hadir secara intangible, berfungsi untuk membedakan keberadaan sebuah produk, sebagai tanda kepemilikan, integritas dan atau untuk membedakannya dari barang-barang dan jasa sejenis yang dihasilkan para pesaing. Merek yang populer merupakan aset yang besar nilainya bagi suatu produk, karena berpengaruh terhadap keputusan konsumen. Konsumen melihat sebuah merek sebagai bagian yang paling penting dalam sebuah produk, dan merek dapat menjadi sebuah nilai tambah dalam produk tersebut (Kotler, 2006, p. 285). Menurut Freddy Rangkuti (2002:2) dikatakan bahwa merek merupakan "janji penjual untuk secara konsisten memberikan feature, manfaat, dan jasa tertentu kepada pembeli", dengan merek maka produsen secara tidak langsung telah mengikat atau menjalin ikatan dengan konsumennya.

Kesadaran akan kehadiran sebuah merek menurut Aaker (1997:9), adalah kesanggupan seorang calon pembeli mengenali atau mengingat kembali bahwa suatu merek merupakan bagian dari kategori produk tertentu. Sementara itu menurut Terence A. Shimp (2003) Kesadaran merek adalah merupakan kemampuan sebuah merek, untuk muncul dalam benak konsumen atau khalayak ketika mereka sedang memikirkan kategori produk tertentu need of product dan 
seberapa mudahnya nama tersebut dimunculkan.

Kesadaran merek ini meliputi beberapa elemen yang dapat diperinci lagi ke dalam dua tingkat kesadaran, yaitu: Brand Recall (kemampuan untuk mengingat Merek) yakni mencerminkan tingkat kesadaran yang lebih dalam dan Brand Recognition (mengenal akan merek) suatu situasi pada tingkat kesadaran yang dangkal konsumen. Merek adalah sesuatu yang dibentuk dalam pikiran pelanggan dan memiliki kekuatan membentuk kepercayaan pelanggan (Peter \& Olson, 1996:168). Jika perusahaan mampu membangun merek yang kuat di pikiran pelanggan melalui strategi pemasaran yang tepat, perusahaan akan mampu membangun mereknya.

Dalam dunia usaha, pemasaran menjadi salah satu mekanisme dalam melepas produk ke konsumen. Istilah pemasaran dalam kacamata manajemen mempunyai dimensi yang lebih luas lagi. Menurut Stanton $(2005 ; 5)$ dikatakan bahwa pemasaran adalah sesuatu yang meliputi seluruh sistem yang berhubungan dengan tujuan untuk merencanakan dan menentukan harga sampai dengan mempromosikan dan mendistribusikan barang dan jasa yang bisa memuaskan kebutuhan pembeli aktual maupun potensial.
Ketika memasarkan maka dibutuhkan suatu strategi agar dapat mencapai tujuan yang diinginkan. Strategi dalam bidang penyedia barang dan jasa dapat diartikan sebagai sebuah rangkaian rancangan besar yang menggambarkan bagaimana sebuah perusahaan harus beroperasi untuk mencapai tujuannya. Kotler (2008:64) sebagai salah seorang pakar manajemen dan pengamat pemasaran, juga mengemukakan bahwa "Pemasaran merupakan proses dimana perusahaan menciptakan nilai bagi pelanggan dan membangun hubungaan yang kuat dengan pelanggan dengan tujuan untuk menangkap nilai dari pelanggan sebagai imbalannya”.

Banyak cara yang dapat digunakan produsen untuk itu, dalam teori pemasaran cara konvensional (yang hingga kini masih dianggap relevan dan moderen) yang biasa dilakukan para pemasar adalah menerapkan prinsip 4P yaitu product, price, place, promotion atau dikenal dengan marketing mix (bauran promosi). Product atau Produk dalam hal ini merujuk pada hasil medium atau formulasi prospek pasar yang akan dimasukinya dan produk macam mana yang diharapkan oleh target pasar. Produk di pasaran dapat berwujud atau berbentuk consumer good yaitu barang yang langsung dapat memuaskan kebutuhan konsumen, 
maupun industrial goods yaitu barang yang mendukung produksi barang konsumsi atau produk tsb dibeli untuk diproduksi kembali dan kemudian baru dipasarkan ke konsumen. Kemudian price (harga) merupakan satuan value atau nilai jual hasil produksi, menetapkan harga diperlukan strategi yang digunakan oleh perusahaan dengan menetapkan harga tinggi untuk menutupi biaya pengembangan produk selanjutnya. Setiap produk memiliki berbagai komponen biayanya sendiri, cara yang umum digunakan adalah dengan menggunakan patokan hitungan biaya produk tersebut dari awal disiapkan hingga siap jual.

Sementara itu place (tempat) merupakan rujukan dimana produk harus dipasarkan, marketing akan selalu mengedepankan masalah penempatan menjadi berarti dan sangat penting. Terakhir promotion adalah ujung tombak cara memasarkan produk agar dapat dikenal konsumen. Promosi secara sederhana dapat dikatakan bagaimana suatu produk akan dikenalkan ke pasar agar pelanggan tergerak untuk membelinya.

Pada poin terakhir itulah, promosi umumnya menjadi bagian yang paling menonjol atau sering disebut dalam kegiatan atau aktivitas pemasaran. Secara singkat dapat dijelaskan bahwa promosi terdiri atas komponen: Periklanan (advertising), merupakan bentuk promosi non personal dengan menggunakan berbagai media yang ditujukan untuk merangsang pembelian. Adapun Penjualan Tatap Muka (personal selling), adalah bentuk promosi secara personal dengan presentasi lisan dalam suatu percakapan dengan calon pembeli yang ditujukan untuk merangsang pembelian. Publisitas (Publicity), menjadi salah satu bentuk promosi non personal mengenai, pelayanan dengan jalan mengulas informasi/berita tentang produknya.

Promosi Penjualan (Sales promotion), adalah bentuk promosi diluar ketiga bentuk diatas yang bertujuan untuk merangsang pembelian, dan pada bagian akhir dari promosi adalah: Pemasaran Langsung (Direct marketing), yakni suatu bentuk penjualan perorangan (interpersonal) secara langsung yang ditujukan untuk mempengaruhi pembelian konsumen (Kasali,1995:10).

\section{Ekuitas Merek}

"Brand equity is a set of assets (and liabilities) linked to a brand's name and symbol that adds to (or substract from) the value provided by a product or service to a firm and or that firm's customers. The major asset categories are: brand awareness; perceived quality; brand associations; and brand loyalty" (Aaker 1991:15). 
Ekuitas merek adalah seperangkat aset terkait dengan nama merek dan simbol yang menambah (atau mengurangi) nilai yang diberikan oleh produk atau jasa ke perusahaan dan atau pelanggan oleh perusahaan. Aset utamanya adalah: kesadaran merek, persepsi atas kualitas, asosiasi merek, dan loyal terhadap merek.

Menurut Terence A. Shimp, ekuitas merek adalah nilai merek yang menghasilkan brand awareness yang tinggi dan asosiasi merek yang kuat, disukai, dan mungkin pula unik, yang diingat konsumen atas merek tertentu. Secara lebih luas ekuitas Merek menurut Aaker dalam Darmadi Durianto, Sugiarto, Sitinjak Tony (2001:4), adalah seperangkat aset dan liabilitas merek yang terkait dengan suatu merek, nama, simbol, yang mampu menambah atau mengurangi nilai sebuah produk atau jasa baik pada perusahaan maupun pada pelanggan. Dikatakan pula oleh Aaker, bahwa ekuitas merek dapat diukur melalui empat dimensi yaitu brand awareness, brand association, perceived quality dan brand loyalty (1991, p. 62). Ekuitas merek diukur berdasarkan 4 (empat) variabel yaitu kesadaran merek, asosiasi merek, persepsi kualitas dan loyalitas merek. Secara umum empat kategori tersebut antara lain meliputi: pertama Kesadaran Merek (brand awareness) menunjukkan kesanggupan seorang calon pembeli untuk mengenali atau mengingat kembali bahwa suatu merek merupakan bagian dari kategori produk tertentu. Menurut Aaker (1996:10) brand awareness adalah kekuatan keberadaan sebuah merek dalam pikiran pelanggan. Kekuatan tersebut ditunjukkan oleh kemampuan pelanggan mengenal dan mengingat sebuah merek.

Kedua adalah Asosiasi Merek (brand association) menunjukkan pencitraan suatu merek terhadap suatu kesan tertentu dalam kaitannya dengan kebiasaan, gaya hidup, manfaat, atribut produk, geografis, harga, selebritis (spoke person) dan lain-lain. Asosiasi merek adalah apapun yang terkait dalam ingatan (memory) pelanggan pada suatu merek.

Menurut Keller (dalam Palupi, 2002), asosiasi memiliki beberapa tipe, yaitu:

a. Atribut (atributes), adalah asosiasi yang dikaitkan dengan atribut-atribut dari merek tersebut baik yang berhubungan langsung terhadap produknya (product related atributes), ataupun yang tidak berhubungan langsung terhadap produknya (non product related atributes) yang meliputi price, user imagery, usage imagery, feelings, experiences, dan brand personality. 
b. Manfaat (benefits), adalah asosiasi suatu merek dikaitkan dengan manfaat dari merek tersebut, baik itu manfaat secara fungsional (functional benefit), manfaat secara simbolik dari pemakainya (symbolic benefit), dan pengalaman yang dirasakan dari penggunanya (experential benefit).

c. Perilaku (Attitudes), adalah asosiasi yang dikaitkan dengan motivasi diri sendiri yang merupakan bentuk perilaku yang bersumber dari bentukbentuk punishment, reward, learning dan knowledge.

Ketiga adalah Persepsi Kualitas (Perceived quality) mencerminkan persepsi pelanggan terhadap keseluruhan kualitas/keunggulan suatu produk atau jasa layanan berkenaan dengan maksud yang diharapkan. Kesan kualitas adalah: “customer's perception of the overall quality or superiority of a product or service with respect to its intended purpose, relatives to alternatives" (Aaker,1991:85).

Kesan kualitas umumnya secara hipotesis dapat dikatakan bersifat obyektif. Kesan kualitas merupakan persepsi pelanggan paling dominan atas atribut yang dinilai menjadi paling penting baginya. Keempat Loyalitas Merek (brand loyalty) mencerminkan tingkat keterikatan konsumen dengan suatu merek produk (Durianto,dkk,2001:4). Loyalitas merek juga merupakan bentuk sikap positif pelanggan dan komitmen pelanggan terhadap sebuah merek di atas merek lainnya (Dharmmesta, 1999:74).

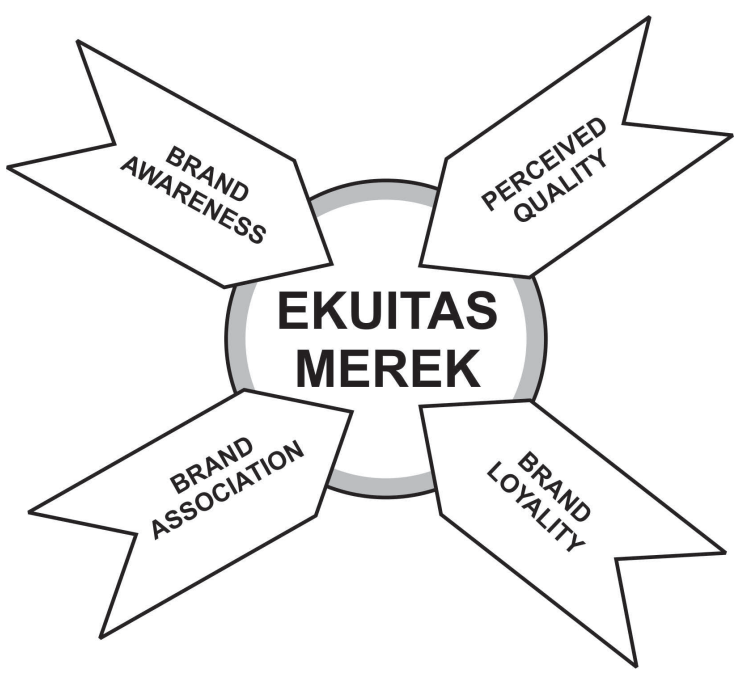

Gambar 1 Empat variabel kesadaran merek yang terbentuk oleh konsumen

Asosiasi terhadap sebuah merek adalah segala sesuatu yang berkaitan secara langsung maupun tidak langsung dengan ingatan konsumen terhadap suatu merek (Aaker: 2001, 167).

Lebih lanjut Aaker (1991, p. 115) menjelaskan pula bahwa asosiasi-asosiasi yang terkait dengan suatu merek dapat dihubungkan sebagaimana pada bagan berikut.

Ekuitas merek pada akhirnya mampu memberikan rasa percaya diri para pelanggan 
"confidence" atas keputusan pembelian produk melalui label mereknya. Keyakinan pelanggan pada suatu merek tidak hanya menimbulkan rasa percaya atas kebenaran tindakan yang diambil akan tetapi memberikan dimensi yang lebih luas dalam kehidupan pribadi yang

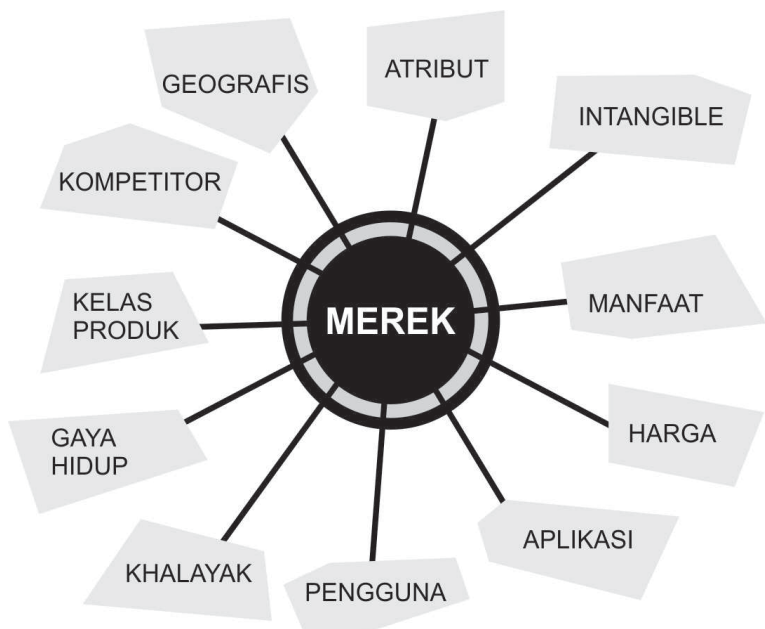

Gambar 2 Asosiasi khalayak terhadap merek Sumber Aaker (1991, p. 115)

menjurus pada tren, gaya hidup atau lifestyle. Dalam pernyataanya Aaker (1991:16) memberikan pandangannya, bahwa rasa percaya diri pelanggan atas keputusan pembelian disebabkan karena kedekatan pelanggan (because of need) dengan merek, hal itu bisa disebabkan oleh aktivitas pengiklanan (persuasive promotion) marak atas kepopuleran merek, kredibilitas merek di mata pelanggan (mass credible), serta pengalaman pelanggan atas merek tersebut (experience consumer).

\section{Loyalitas Merek}

Menelaah loyalitas konsumen, merupakan salah satu hal penting yang harus selalu harus dilakukan oleh perusahaan agar pelanggan selalu loyal terhadap merek dan tidak berganti merek. Mempertahankan semua pelanggan yang ada pada umumnya, akan lebih menguntungkan dibandingkan dengan pergantian pelanggan karena biaya untuk menarik pelanggan baru bisa lima kali lipat dari biaya mempertahankan seorang pelanggan yang sudah ada. (Kotler, 2007:207) Loyalitas merek juga merupakan bentuk sikap positif pelanggan dan komitmen pelanggan terhadap sebuah merek di atas merek lainnya (Dharmmesta, 1999:74).

Terdapat keuntungan-keuntungan yang akan diperoleh oleh perusahaan apabila memiliki konsumen yang loyal (Griffin, 2005:11) Aaker (1991:42) menyatakan bahwa loyalitas merek tidak terjadi tanpa melalui tindakan pembelian dan pengalaman menggunakan suatu merek sebelumnya. Hal ini membedakan loyalitas merek dengan elemen ekuitas merek lainnya di mana pelanggan memiliki kesadaran merek, kesan kualitas, dan asosiasi merek tanpa terlebih dahulu membeli dan menggunakan merek. 
Seorang pelanggan yang sangat loyal kepada suatu merek tidak akan dengan mudah memindahkan pembeliannya ke merek lain, apa pun yang terjadi dengan merek tersebut.

Aaker (1997:56) mendefinisikan loyalitas merek (brand loyalty) sebagai suatu ukuran keterkaitan pelanggan kepada sebuah merek. Ukuran ini mampu memberikan gambaran tentang mungkin tidaknya seorang pelanggan beralih ke merek lain yang ditawarkan oleh kompetitor, terutama jika pada merek tersebut didapati adanya perubahan, baik menyangkut harga ataupun atribut lainnya.

Menurut Zaltman, (1979:288) bahwa merek adalah: "loyalty is one type of repeat purchase." Bahwa dengan mengulangi pembelian merupakan suatu bentuk kesetiaan merek. Bila banyak pelanggan dari suatu merek masuk dalam kategori ini berarti merek tersebut memiliki brand equity yang kuat. Menurut Rangkuti (2004) apabila para konsumen beranggapan bahwa merek tertentu secara fisik berbeda dari merek pesaing, citra merek tersebut akan melekatsecara terus-menerus sehingga dapat membentuk kesetiaan terhadap merek tertentu yang pada akhirnya akan menciptakan loyalitas pelanggan.

\section{Motif Pembelian atas merek}

Aaker (1991: 62) menggambarkan level kesadaran pelanggan terhadap merek dalam bentuk piramida sebagai berikut:

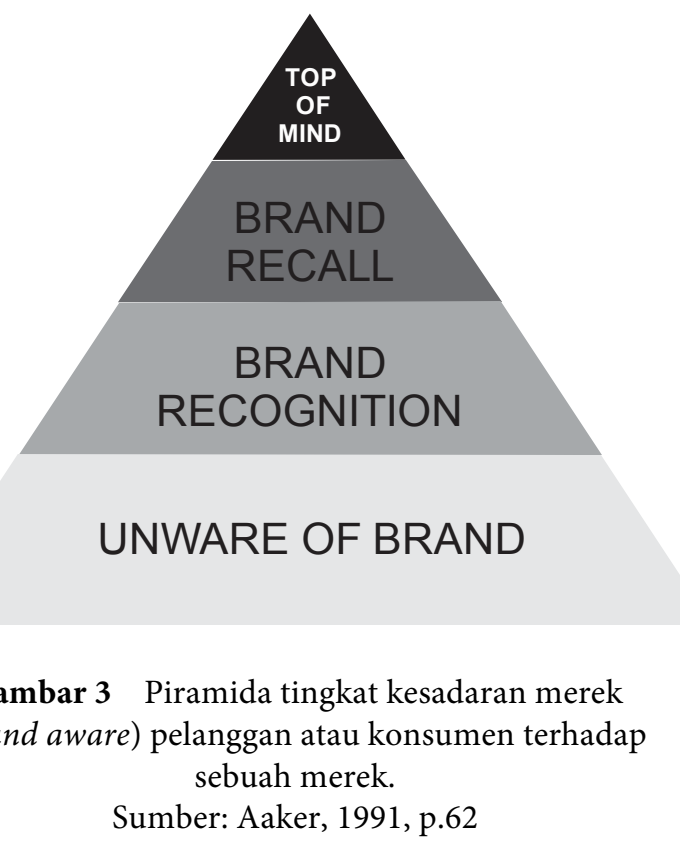

Secara garis besar, piramida di atas dapat dijelaskan sebagai berikut:

1. Tidak sadar merek (unaware of brand), adalah level yang paling rendah. Pada posisi ini pelanggan sama sekali tidak mengenali merek yang disebutkan meskipun melalui alat bantu, seperti menunjukkan gambar atau menyebutkan nama merek tersebut.

2. Mengenali merek (brand recognition), tahapan ini terjadi ketika sesorang dapat mengingat kembali dengan bantuan. Pada level ini, pelanggan akan 
mengingat merek setelah diberikan bantuan dengan memperlihatkan gambar atau ciri-ciri tertentu.

3. Mengingat kembali merek (brand recall), adalah level pengingatan merek tanpa bantuan (unaided recall). Level ini mencerminkan merek-merek yang dapat diingat pelanggan dengan baik tanpa bantuan.

4. Puncak pikiran (top of mind) , merupakan level tertinggi dan posisi ideal bagi semua merek. Pada level ini, pelanggan sangat paham dan mengenali elemen-elemen yang dimiliki sebuah merek. Pelanggan akan menyebutkan merek untuk pertama kali, saat ditanya mengenai suatu kategori produk. Dengan perkataan lain, sebuah merek menjadi merek utama dari berbagai merek yang ada dalam benak pelanggan.

Motif pembelian atas merek, tampaknya harus disadari oleh produsen bahwa menetapkan merek sebagai salah satu strategi mengendalikan pasar menjadi tidak begitu menguntungkan. Merek sebagai brand yang kuat serta mampu menjual, memerlukan serangkaian proses panjang tidak hanya sekedar melakukan strategi advertising saja akan tetapi celah lain mesti harus ditempuh.

\section{Sikap dan Loyalitas Konsumen atas Merek}

Dalam banyak hal, sikap terhadap merek tertentu sering mempengaruhi apakah konsumen akan loyal atau tidak. Persepsi yang baik dan kepercayaan konsumen akan suatu merek tertentu akan menciptakan minat beli konsumen dan bahkan meningkatkan loyalitas konsumen terhadap produk tertentu. Semakin kecil tingkat perceived risk suatu merek, semakin besar keyakinan pelanggan atas keputusan pembeliannya, dengan demikian pelanggan memiliki keyakinan yang besar atas outcome of the decision. (Aaker, 1991:65; Keller, 1998:92).

Teori penghubung antara citra merek dengan loyalitas konsumen dikutip dari Freddy Rangkuti (2002: 34) yang mengatakan: "Apabila konsumen beranggapan bahwa merek tertentu secara fisik berbeda dari merek pesaing, citra merek tersebut akan melekat secara terus menerus sehingga dapat membentuk kesetiaan terhadap merek tertentu yang disebut dengan loyalitas merek". Produsen harus mampu mempertahankan kualitas jaminan produk melalui merek, sehingga konsumen akan loyal terhadap produk yang sudah tertanam dibenaknya. Menurut Assael (1995:31) loyalitas adalah suatu sikap positif terhadap sesuatu yang manghasilkan pembelian yang 
konsisten sepanjang waktu. Selanjutnya Griffin (2005:5) berpendapat bahwa seorang pelanggan dikatakan setia atau loyal apabila pelanggan tersebut menunjukkan perilaku pembelian secara teratur atau terdapat suatu kondisi dimana mewajibkan pelanggan membeli paling sedikit dua kali dalam selang waktu tertentu. Pada akhirnya dapat dikatakan bahwa terdapat hubungan antara citra merek dengan loyalitas konsumen dimana hal itu terletak pada pilihan konsumen untuk membedakan objek pilihannya (preference) atas suatu merek dan itu mutlak sepenuhnya merupakan milik dan sikap konsumen.

\section{Marketing Communication}

Untuk mendukung kegiatan di atas, pendekatan atau cara yang dapat digunakan untuk menekan penjualan atas merek salah satunya antara lain adalah melalui Integrated Marketing Communication (IMC). Komunikasi pemasaran terpadu adalah sebuah konsep dimana suatu perusahaan mengintegrasikan dan mengkoordinasikan berbagai saluran komunikasi untuk mengirim pesan yang jelas, konsisten, dan meyakinkan berkenaan dengan perusahaan dan produknya. (Kotler dan Amstrong; 2005).

Tujuan yang ingin dicapai IMC adalah untuk memengaruhi masyarakat dengan elemen promosinya sampai ke tingkat kognisi, afeksi, dan konasi. Advertising, public relation, interactive marketing untuk memengaruhi konsumen ke tingkat kognisi dan afeksi. Sedangkan, personal selling, direct marketing, sales promotion untuk memengaruhi konsumen ke tingkat konasi.

Uyung Sulaksana

$(2003: 31)$

menambahkan bahwa konsep IMC telah diperluas dari sekedar untuk kepentingan pemasaran, menjadi lebih komprehensif dan menyentuh berbagai aspek yang terkait dengan perusahaan.

Secara rinci oleh Rangkuti dikatakan bahwa komunikasi pemasaran terpadu adalah sebuah proses perencanaan marketing komunikasi yang memperkenalkan konsep perencanaan komprehensif untuk mengevaluasi peranan strategis dari berbagai elemen komunikasi pemasaran, seperti advertising yaitu komunikasi non individu dengan sejumlah biaya, melalui berbagai media yang dilakukan oleh pelaku usaha, lembaga nirlaba atau individu.

Sales promotion adalah salah satu kegiatan promosi untuk melakukan rangsangan kepada konsumen guna mendorong pembelian. Personal selling adalah penjualan perseorangan melalui interaksi antar individu, saling bertemu muka yang ditujukan untuk menciptakan, 
memperbaiki, mempertahankan pertukaran hubungan yang saling menguntungkan.

Public relation dalam kegiatan IMC, merupakan ajang kegiatan yang tidak kalah penting dan menarik, melalui aktifitas ini maka publikasi dapat dilakukan secara lebih nyata, dan Publicity, usaha untuk merangsang permintaan terhadap suatu produk secara nonpersonal denagn membuat berita yang bersifat komersial tentang sebuah produk dalam media cetak ataupun tidak tercetak.

Kontinuitas membangun pasar dan merek secara otomatis akan terbina melalui kegiatan ini. Kegiatan lain adalah memposisikan perusahaan (merek) sebagai satu-satunya pilihan dibanding dengan merek lain. Konsumen secara nyata harus dipikat untuk selalu loyal terhadap merek, sebagai jaminan maka perusahaan memberikan layanan atau servis yang memposisikan pembeli adalah raja. Dalam hal ini maka sikap percaya konsumen harus diimbangi dengan kegiatan nyata dari perusahaan.

Loyalitas merek tidak semata hanya perduli atau memperhatikan merek sebagai label atau sebuah sebutan, akan tetapi mempunyai implikasi atau dimensi yang lebih luas antara lain: antara lain menjamin ekuitas merek sehingga membuat konsumen nyaman dan loyal terhadap merek.
Tugas marketing communication disini dituntut peran yang lebih besar, dalam jangka panjang tentunya harus mempunyai planning yang tepat agar kontinuitas terjalinya komunikasi di antara keduanya dapat abadi. Manfaat IMC bagi organisasi atau perusahaan, di antaranya: membentuk identitas merk yang kuat di pasar dengan mengikat bersama dan memperkuat semua citra dan pesan komunikais perusahaan. Mengkoordinasikan semua pesan, positioning dan citra, serta identitas perusahaan melalui semua bantuk komunikasi pemasaran.

Menurut Duncan (2005), komunikasi pemasaran terpadumerupakan proses perencanaan, pelaksanaan dan pengendalian pesan atas sebuah merek untuk dapat diciptakan hubungan jangka panjang dengan pelanggan. Adanya hubungan yang lebih erat antara perusahaan (melaui produk/jasanya) dengan para konsumennya. IMC menjadi sebuah solusi bagi agensi periklanan dalam menjangkau berbagai segmentasi pelanggan yang mengkonsumsi beragam media. Melalui IMC ini maka tidak sekedar terjadi kegiatan yang bersifat promosi akan tetapi juga menjadi ajang promosi kegiatan langsung. 


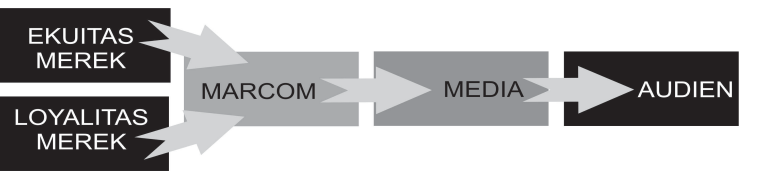

Gambar 4 Sinergi dalam membangun merek Bersama marketing communication kepada audien

\section{KESIMPULAN}

Berbicara tentang ekuitas merek, maka merek menjadi salah satu capaian ukuran dalam menunjukkan keunggulan bagi perusahaan untuk memenangkan persaingan. Sebuah merek yang kuat mempunyai kelebihan, disaat perusahaan memasuki titik jenuh atau fase kritis penjualan, krisis produksi atau terbentur pada situasi kemungkinan terjadinya pergeseran pilihan selera konsumen, merek tetap mempunyai nilai tawar.

Membangun ekuitas merek, adalah menjadi bagian penting dalam mengelola merek. Ekuitas merek dapat memberi kontribusi berupa manfaat bagi suatu perusahaan. Ekuitas merek dapat memberikan sejumlah keunggulan kompetitif bagi suatu perusahaan. Sebab disini sebuah perusahaan selalu dituntut untuk dapat mempertahankan pasar melalui cara masingmasing.

Adapun tingkat ekuitas merek yang tinggi umumnya dapat mengarah pada tingginya preferensi dan menjadi pilihan tingkat daya beli konsumen. Namun demikian jika tidak berhati-hati, tidak selalu merek juga dapat menjadi jaminan dalam menjaga nilai value produk atau penjualan. Menurut Kotler dan Keller (dalam Killa, 2008: 427) mengatakan bahwa meskipun promosi penjualan telah lebih banyak diterima oleh manajemen sebagai alat yang efektif, akan tetapi promosi penjualan yang membabi buta justru dapat pula mempengaruhi citra merek.

IMC sebagai bagian dari strategi promosi merupakan suatu sinergi, kreativitas, integrasi dan komunikasi pemasaran secara terpadu dimana memanfaatkan beragam elemen komunikasi yang berbeda namun tetap tercipta koherensi, kontinuitas yang saling mendukung sehingga ekuitas merek akan tetap tertanam di benak khalayak dan konsumen akan selalu loyal terhadap merek.

\section{DAFTAR PUSTAKA}

[1] Assael, Henry. (1995). Consumer Behavior and Marketing Action. Fifth Edition. Cincinnati Ohio. South-Western College Publishing

[2] Aaker, David A. (1991). Managing Brand Equity: Capitalizing on the Value of a Brand Name. NY: The Free Press.

[3] Aaker. (2001). Strategic Market Management. USA: John Wiley \& Sons, INC.

[4] Durianto, Darmadi. Sugiarto dan toni Sitinjak. (2001). Strategi Menaklukkan Pasar: Melalui Riset Ekuitas dan Perilaku Merek. Jakarta: PT Gramedia Pustaka Utama. 
[5] David, Aaker A. (1997). Manajemen Ekuitas Merek. Jakarta: Penerbit Mitra Utama.

[6] David, Aaker, A. (1991). Managing Brand Equity: Capitalizing on the Value of a Brand Name. NY: The Free Press.

[7] David, Aaker., (1996). Building Strong Brands. NY: The Free Press.

[8] Dharmmesta, Basu Swastha. (1999). Loyalitas pelanggan: Sebuah kajian Konseptual Sebagai Panduan bagi Peneliti. Jurnal Ekonomi dan Bisnis Indonesia. Vol.14, No.3:

[9] Griffin, Jill. (2005). Customer Loyalty: Menumbuhkan dan Mempertahankan Kesetiaan Pelanggan. Jakarta: Penerbit Erlangga,

[10] Keller, Kevin Lane. (1998). Strategic Brand Management: Building, Measuring, and Managing Brand Equity. NJ: Prentice Hall.

[11] Kotler P \& Amstrong G. (2005) "Principle of Marketing", $10^{\text {th }}$ edition/ International Edition, Prentice Hall, New Jersey, 2004.

[12] Duncan, Tom. Principles of Advertising \& IMC. Second Edition. Mc.GrawHill, Inc. Bab 18.

[13] Kotler, Philip. (2006). Manajemen Pemasaran Jilid 1 edisi 11, Jakarta: PT. Index Kelompok Gramedia.

[14] Killa, Maklon Felipus. (2008). Pengaruh Pembelanjaan Periklanan Dan Promosi Harga Pada Ekuitas Merek, Jurnal Ekonomi dan Bisnis Indonesia Vol.23, No. 4, 2008.

[15] Kotler, P. and Armstrong, G. (2006). Principles of marketing ( $\left.11^{\text {th }} e d.\right)$. NJ: Prentice Hall.

[16] Kotler, Philip., Kevin Lane Keller. (2007). Manajemen Pemasaran Edisi 12 Jilid 1. Jakarta: Indeks-Prentice Hall,

[17] Kasali, Rhenald. (1995). Manajemen Perikalanan Konsep dan Aplikasinya di Indonesia, PAU UI. Jakarta: Pustaka Utama Grafiti.
[18] Peter, Paul J. dan Jerry C. Olson. (1996). Consumer Behavior and Marketing Strategy. Fourth Edition. Richard D. Irwin Inc. Terjemahan: Damos Sihombing. Jakarta: Erlangga.

[19] Palupi, Dyah Hasto. (2002). Membangun Personalitas Merek. USAHAWAN. No.10/XXXI/10.

[20] Rangkuti, Freddy. (2009). Strategi Promosi Yang Efektif, Penerbit Gramedia Jakarta,

[21] Tom Duncan. (2005). Principle of Advertising and Integrated Marketing Communicatioan, $2^{\text {nd }}$ Edition. NY: McGraw Hill.

[22] Rangkuti, Freddy. (2002). The Power of Brands: Teknik Mengelola Brand Equity dan Strategi Pengembangan Merek + Analisis Kasus dengan SPSS. Jakarta: PT Gramedia Pustaka Utama.

[23] Stanton, William J. (1991). Prinsip Pemasaran. Alih Bahasa Wilhelmus W. Bokowatun, Jakarta: Erlangga.

[24] Sulaksana, Uyung. (2003). Merek n Komunikasi Pemasaran Terpadu, Manajemen Perubahan,

[25] Terence, A, Shimp. (2003). Periklanan Promosi \& Aspek Tambahan Komunikasi Pemasaran Terpadu, Jilid I (edisi 5), Jakarta Erlangga.

[26] Zaltman. (1978). Organizational Buying Behaviour, American Marketing Association. 